HEALTHCARE DELIVERY

\title{
Patient support interventions to improve adherence to drug-resistant tuberculosis treatment: A counselling toolkit
}

\author{
E Mohr, J Hughes, L Snyman, B Beko, X Harmans, J Caldwell, H Duvivier, L Wilkinson, V Cox
}

Erika Mohr, drug-resistant tuberculosis (DR-TB) epidemiologist at Médecins Sans Frontières (MSF) Khayelitsha, Cape Town, South Africa, obtained a Master's in Public Health from Boston University (USA), concentrating in epidemiology. Her special interests include infectious diseases, maternal and child health and developing health care systems. Jennifer Hughes, DR-TB doctor at MSF Khayelitsha, graduated MB BCh and BSc Hons (Public Health) from Cardiff University in Wales and completed a Diploma in Tropical Medicine and Hygiene (DTMH) in Liverpool. Leigh Snyman, DR-TB patient support manager at MSF Khayelitsha, graduated with a Diploma in General Nursing and has completed a short course in palliative nursing care. Busisiwe Beko, a DR-TB counsellor at MSF Khayelitsha, is studying for a degree in social work. Her special interests include patient-centred models of care, particularly for patients with DR-TB. Xoliswa Harmans is also a DR-TB counsellor at MSF Khayelitsha. As a former extensively drug-resistant tuberculosis patient, she is interested in the provision of structured patient support for DR-TB. Judy Caldwell, a registered nurse with a BCur degree, is TB project manager at the Department of Health for the City of Cape Town. Hélène Duvivier, patient and community support advisor at MSF South Africa and Lesotho, is a clinical sexotherapist with a master's degree in Sciences of Family and Sexuality from Louvain-laNeuve University, Belgium. Lynne Wilkinson, project co-ordinator of the HIV/TB Programme at MSF Khayelitsha, is a qualified attorney with a master's degree in Global Health. Her special interests include HIV and TB retention and adherence strategies, focusing on community models of care and patient support-related interventions. Vivian Cox, MD, current deputy field co-ordinator of the HIV/TB Programme at MSF Khayelitsha, is particularly interested in infectious diseases and recently completed an MSF mission in Liberia to provide assistance with the Ebola outbreak.

Corresponding author: E Mohr (msfocb-khayelitsha-drtb-epi@brussels.msf.org)

In response to the growing burden of drug-resistant tuberculosis (DR-TB) in South Africa (SA), Médecins Sans Frontières (MSF), with local government health departments, piloted a decentralised model of DR-TB care in Khayelitsha, Western Cape Province, in 2007. The model takes a patient-centred approach to DR-TB treatment that is integrated into existing TB and HIV primary care programmes. One essential component of the model is individual and family counselling to support adherence to and completion of treatment. The structured and standardised adherence support sessions have been compiled into a DR-TB counselling toolkit. This is a comprehensive guide that focuses on DR-TB treatment literacy, adherence strategies to encourage retention in care, and provision of support throughout the patient's long treatment journey. Along with other strategies to promote completion of treatment, implementation of a strong patient support component of DR-TB treatment is considered essential to reduce rates of loss from treatment among DR-TB patients. We describe our experience from the implementation of this counselling model in a high DR-TB burden setting in Khayelitsha, Cape Town, SA.

S Afr Med J 2015;105(8):631-634. DOI:10.7196/SAMJnew.7803

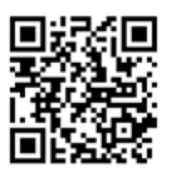

Drug-resistant tuberculosis (DR-TB), defined as TB with at least rifampicin resistance, is increasing in prevalence and incidence worldwide. ${ }^{[1]}$ South Africa (SA) has reported some of the highest numbers of DR-TB cases globally: in 2012 alone there were 14161 laboratorynotified cases of multidrug-resistant TB (MDR-TB) and 1545 cases of extensively drug-resistant TB (XDR-TB).$^{[2]}$ Regimens available for DR-TB are expensive, toxic, and require a minimum treatment duration of 20 months. In addition, currently available medications often cause multiple side-effects that impact on patients' ability to maintain their usual daily activities. ${ }^{[3]}$ The burden of treatment regimens contributes to poor DR-TB programme outcomes, including high rates of loss from treatment (LFT) and stagnant treatment success rates. A study conducted in the Western Cape Province, SA, found an LFT rate of $27 \%$, which is comparable to LFT rates observed in other DR-TB treatment cohorts in SA. ${ }^{[4]}$ National Department of Health (NDoH) data from 2012 reflect a 40\% treatment success rate for MDR-TB and less than $20 \%$ treatment success for XDRTB. ${ }^{[2]}$ It is imperative that strategies to provide structured patient support are developed and implemented to promote retention in care.

\section{Setting}

Khayelitsha, a township in the Western Cape, is home to approximately 500000 people and has one of the highest rates of
HIV and TB among subdistricts in the country. It was determined that there were 989 cases of DR-TB diagnosed in Khayelitsha from 2003 through 2010, 200 of which were diagnosed in 2010. In response to the growing burden of DR-TB in Khayelitsha, Médecins Sans Frontières (MSF) collaborated with City of Cape Town Department of Health (CCTDoH) and provincial health services in 2007 to pilot a decentralised model of care in which primary healthcare clinicians initiate and manage treatment of patients diagnosed with DR-TB at Khayelitsha-based clinics. The prevailing model of care for DR-TB previously involved centralisation of treatment to 45 specialised hospitals in SA, which hindered the ability to provide longitudinal support to DR-TB patients and their families in their local community. In contrast, decentralisation to primary care enabled patient support to form a major component of the overall model of care. ${ }^{[5]}$ Two dedicated lay DR-TB counsellors were employed to provide education and support to DR-TB patients managed at 11 primary care clinics in the subdistrict. Since 2011 the model has been managed by the $\mathrm{CCTDoH}$, and various aspects of the model have been adopted and implemented across other subdistricts in the Western Cape. In 2012, MSF, together with the $\mathrm{CCTDoH}$, developed a more structured, standardised, patientcentered approach to counselling DR-TB patients, placing equal emphasis on treatment literacy and adherence support. 


\section{Objective}

A policy of decentralised management of DR-TB in SA was endorsed by the $\mathrm{NDoH}$ in 2011. Although welcomed for its prioritisation of decentralisation nationally, it lacks specific information on how to provide structured patient support and counselling despite its recommendation to provide these services to patients. The DR-TB counselling toolkit aims to provide guidance on how to provide patient support to promote adherence to difficult treatment regimens, to encourage retention in care, and to increase the likelihood of successful treatment outcomes.

\section{The intervention}

The counselling toolkit is a comprehensive guide that provides patients with support throughout the duration of their treatment. It aims to encourage patients to take ownership of their treatment. Specific counselling session plans have been included in the toolkit that provide structured scripts of simple key points to convey to patients,

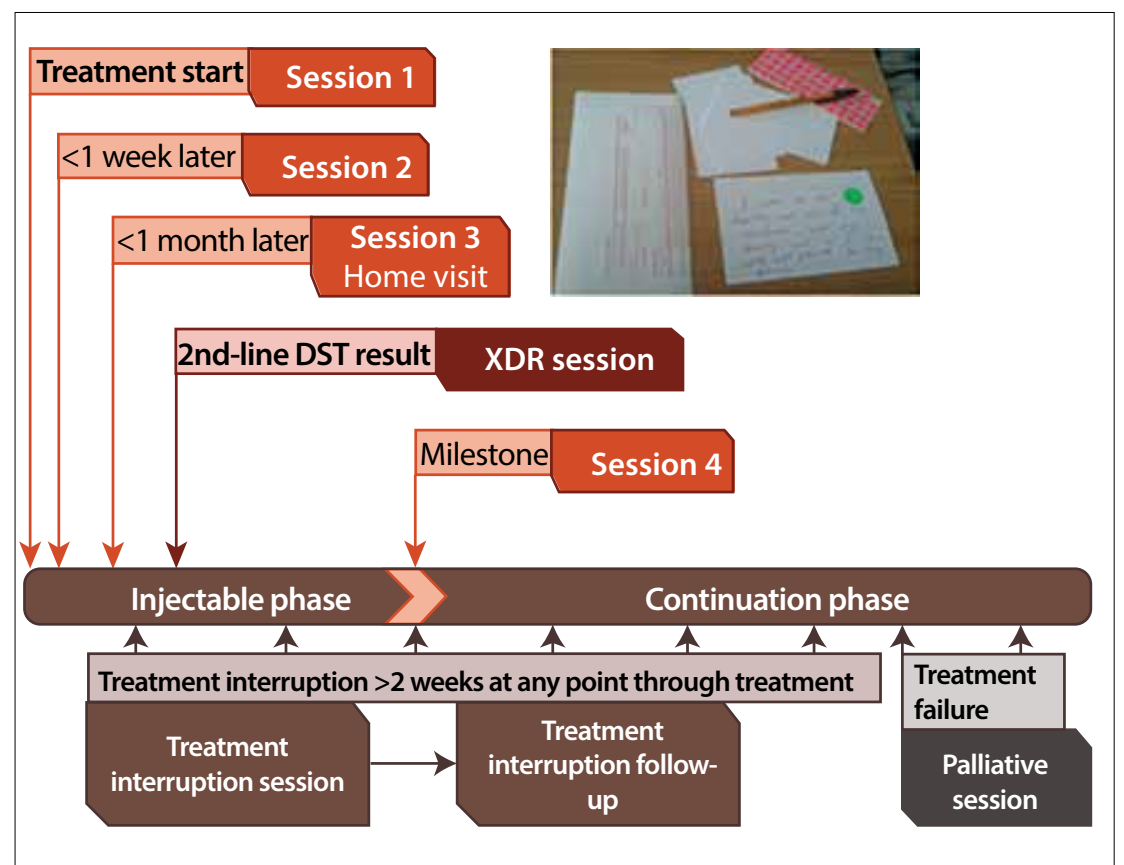

Fig. 1. Overview of the counselling sessions. ${ }^{\left[{ }^{6]}\right.}$ (DST $=$ drug susceptibility testing.)

Table 1. Timing of DR-TB counselling sessions ${ }^{[6]}$

\begin{tabular}{|c|c|c|c|c|c|}
\hline Session & Target & Rationale & Timing and location & Session content & $\begin{array}{l}\text { Resource } \\
\text { materials }\end{array}$ \\
\hline Session 1 & $\begin{array}{l}\text { Newly diagnosed } \\
\text { DR-TB patients }\end{array}$ & $\begin{array}{l}\text { Provide the patient with } \\
\text { information regarding } \\
\text { DR-TB to promote } \\
\text { insight about their } \\
\text { disease, adherence to } \\
\text { treatment, and ownership } \\
\text { of their treatment journey } \\
\text { To plan with the } \\
\text { counsellor how to } \\
\text { overcome possible } \\
\text { barriers to treatment } \\
\text { adherence }\end{array}$ & $\begin{array}{l}\text { First day of treatment } \\
\text { initiation } \\
\text { Clinic }\end{array}$ & $\begin{array}{l}\text { Treatment literacy } \\
\text { Basic TB and DR-TB information } \\
\text { including definitions, when and } \\
\text { where to take treatment, and clinic } \\
\text { visits; basic awareness of side- } \\
\text { effects and other treatment-related } \\
\text { challenges; basic infection control } \\
\text { Adherence steps } \\
\text { Step 1: Getting to appointments } \\
\text { Step 2: Dealing with side-effects } \\
\text { Step 3: Getting support at home } \\
\text { Step 4: Getting support at the clinic } \\
\text { Step 5: Audiometry screening } \\
\text { Identify three reasons to stay } \\
\text { healthy and alive }\end{array}$ & $\begin{array}{l}\text { Session plan - } \\
\text { session } 1 \\
\text { Flip chart } \\
\text { Adherence plan } \\
\text { Stickers }\end{array}$ \\
\hline $\begin{array}{l}\text { Session } 2 \\
\text { (may be } \\
\text { combined } \\
\text { with } \\
\text { session 3) }\end{array}$ & $\begin{array}{l}\text { DR-TB patients } \\
\text { who have received } \\
\text { counselling } \\
\text { session } 1\end{array}$ & $\begin{array}{l}\text { Provide the patient with } \\
\text { information regarding } \\
\text { DR-TB to promote } \\
\text { insight into their } \\
\text { disease and adherence } \\
\text { to treatment, and allow } \\
\text { patient to take ownership } \\
\text { of the treatment journey } \\
\text { as they plan with the } \\
\text { counsellor how to } \\
\text { overcome possible } \\
\text { barriers to adherence to } \\
\text { treatment }\end{array}$ & $\begin{array}{l}\text { Within } 1 \text { week of } \\
\text { treatment initiation } \\
\text { Home or clinic }\end{array}$ & $\begin{array}{l}\text { Treatment literacy } \\
\text { Basic information regarding } \\
\text { adherence and what to expect if } \\
\text { adherence is poor; discussing the } \\
\text { importance of identifying drugs } \\
\text { and dosages; definitions of sputum } \\
\text { and culture conversion } \\
\text { Adherence steps } \\
\text { Step 6: Preventing future mistakes } \\
\text { and completing the treatment } \\
\text { journey } \\
\text { Step 7: Identifying a treatment } \\
\text { partner } \\
\text { Step 8: Communicating with the } \\
\text { treatment team } \\
\text { Step 9: How to manage weekend } \\
\text { doses } \\
\text { Step 10: Reminder strategies }\end{array}$ & $\begin{array}{l}\text { Session plan - } \\
\text { session } 2 \\
\text { Flip chart } \\
\text { Adherence plan } \\
\text { Stickers }\end{array}$ \\
\hline
\end{tabular}


Table 1. (continued) Timing of DR-TB counselling sessions ${ }^{[6]}$

\begin{tabular}{|c|c|c|c|c|c|}
\hline Session & Target & Rationale & Timing and location & Session content & $\begin{array}{l}\text { Resource } \\
\text { materials }\end{array}$ \\
\hline $\begin{array}{l}\text { Session } 3 \\
\text { (may be } \\
\text { combined } \\
\text { with } \\
\text { session 2) }\end{array}$ & $\begin{array}{l}\text { DR-TB patients } \\
\text { who have received } \\
\text { counselling } \\
\text { session } 2\end{array}$ & $\begin{array}{l}\text { Provide DR-TB } \\
\text { information to the } \\
\text { family and the patient, } \\
\text { encouraging the } \\
\text { family to support the } \\
\text { patient; DR-TB contact } \\
\text { identification, screening } \\
\text { and infection control } \\
\text { advice }\end{array}$ & $\begin{array}{l}\text { Within the first month } \\
\text { of treatment initiation } \\
\text { Home (if the patient } \\
\text { refuses a home visit, } \\
\text { this session can be } \\
\text { done in the clinic } \\
\text { with a family member } \\
\text { joining the patient) }\end{array}$ & $\begin{array}{l}\text { Treatment literacy } \\
\text { Basic TB and DR-TB information: } \\
\text { TB infection control and how TB } \\
\text { is spread; time off work or school; } \\
\text { patient journey; details of those } \\
\text { at risk of DR-TB and contacts } \\
\text { in the home; TB and pregnancy; } \\
\text { traditional medication and alcohol } \\
\text { use with treatment } \\
\text { Adherence steps } \\
\text { Step 11: How to protect my family } \\
\text { Step 12: How to deal with } \\
\text { substance abuse } \\
\text { Step 13: Managing unplanned trips }\end{array}$ & $\begin{array}{l}\text { Session plan - } \\
\text { session } 3 \\
\text { Flip chart } \\
\text { Adherence plan }\end{array}$ \\
\hline Session 4 & $\begin{array}{l}\text { DR-TB patients } \\
\text { who have } \\
\text { completed the } \\
\text { intensive phase }\end{array}$ & $\begin{array}{l}\text { Congratulate the patient } \\
\text { and revise treatment } \\
\text { literacy messages and } \\
\text { adherence steps to ensure } \\
\text { ongoing adherence } \\
\text { (also inform patient } \\
\text { of potential for self- } \\
\text { administered treatment } \\
\text { (SAT) in some settings) }\end{array}$ & $\begin{array}{l}\text { Completion of } \\
\text { intensive phase } \\
\text { Clinic }\end{array}$ & $\begin{array}{l}\text { Revision of treatment literacy } \\
\text { messages } \\
\text { See sessions } 1 \text { - } 3 \\
\text { Revisit adherence steps } \\
\text { See sessions } 1 \text { - } 3\end{array}$ & $\begin{array}{l}\text { Session plan - } \\
\text { session } 4 \\
\text { Flip chart } \\
\text { Adherence } \\
\text { plan that was } \\
\text { completed } \\
\text { post treatment } \\
\text { initiation }\end{array}$ \\
\hline $\begin{array}{l}\text { Treatment } \\
\text { interruption } \\
\text { session }\end{array}$ & $\begin{array}{l}\text { Patients who } \\
\text { interrupted } \\
\text { DR-TB treatment } \\
\text { for } \geq 2 \text { consecutive } \\
\text { weeks or who } \\
\text { frequently } \\
\text { interrupt } \\
\text { treatment for } \\
\text { short time periods }\end{array}$ & $\begin{array}{l}\text { Promote adherence to } \\
\text { treatment and prevent } \\
\text { LFT }\end{array}$ & $\begin{array}{l}\text { As soon as the patient } \\
\text { has interrupted } \\
\text { DR-TB treatment for } \\
2 \text { consecutive weeks, } \\
\text { or if the patient } \\
\text { frequently interrupts } \\
\text { treatment for short } \\
\text { time periods } \\
\text { Clinic or home }\end{array}$ & $\begin{array}{l}\text { Treatment literacy } \\
\text { What is adherence, what happens } \\
\text { if you take your treatment, and } \\
\text { what happens if you stop taking } \\
\text { your treatment } \\
\text { Adherence steps } \\
\text { Step 1: Reminder strategies } \\
\text { Step 2: Getting to the clinic } \\
\text { Step 3: Getting support at home } \\
\text { Step 4: DR-TB support at the clinic } \\
\text { Step 5: Dealing with side-effects } \\
\text { Step 6: Dealing with substance use } \\
\text { Step 7: Completing your treatment } \\
\text { journey }\end{array}$ & $\begin{array}{l}\text { Session plan - } \\
\text { treatment } \\
\text { interruption } \\
\text { session } \\
\text { Flip chart } \\
\text { Adherence plan }\end{array}$ \\
\hline $\begin{array}{l}\text { Treatment } \\
\text { interruption } \\
\text { follow-up } \\
\text { sessions }\end{array}$ & $\begin{array}{l}\text { Patients who } \\
\text { received the } \\
\text { treatment } \\
\text { interruption } \\
\text { session }\end{array}$ & $\begin{array}{l}\text { Monitor adherence on } \\
\text { a frequent basis and } \\
\text { improve the patient- } \\
\text { healthcare worker } \\
\text { relationship }\end{array}$ & $\begin{array}{l}\text { One week after the } \\
\text { treatment interruption } \\
\text { counselling session } \\
\text { Clinic }\end{array}$ & $\begin{array}{l}\text { Follow-up session } \\
\text { Monitor goals achieved, set new } \\
\text { goals }\end{array}$ & $\begin{array}{l}\text { Adherence plan } \\
\text { Nurse } \\
\text { monitoring } \\
\text { document }\end{array}$ \\
\hline $\begin{array}{l}\text { XDR-TB } \\
\text { session }\end{array}$ & $\begin{array}{l}\text { Patients with a } \\
\text { pre-XDR or XDR- } \\
\text { TB diagnosis }\end{array}$ & $\begin{array}{l}\text { Educate the patient } \\
\text { on pre-XDR and XDR } \\
\text { diagnosis, discuss potential } \\
\text { future treatment options } \\
\text { and limitations (the } \\
\text { clinician will continue } \\
\text { this discussion), create an } \\
\text { awareness of palliative care }\end{array}$ & $\begin{array}{l}\text { As soon as possible } \\
\text { after second-line } \\
\text { resistance has been } \\
\text { detected } \\
\text { Clinic }\end{array}$ & $\begin{array}{l}\text { Treatment literacy } \\
\text { Adherence assessment } \\
\text { Step 1: Confirming the patient's } \\
\text { support system at home } \\
\text { Step 2: Reviewing contacts for } \\
\text { screening } \\
\text { Step 3: SOS plan for emergencies }\end{array}$ & $\begin{array}{l}\text { Session plan - } \\
\text { XDR-TB session } \\
\text { Adherence } \\
\text { assessment }\end{array}$ \\
\hline $\begin{array}{l}\text { Palliative } \\
\text { care session }\end{array}$ & $\begin{array}{l}\text { Patients in whom } \\
\text { DR-TB treatment } \\
\text { has failed, } \\
\text { and have been } \\
\text { identified as such } \\
\text { by a clinician }\end{array}$ & $\begin{array}{l}\text { Understanding their } \\
\text { diagnosis and prognosis, } \\
\text { future treatment and } \\
\text { psychosocial support } \\
\text { options }\end{array}$ & $\begin{array}{l}\text { As soon as the patient } \\
\text { is identified by a } \\
\text { clinician as a patient } \\
\text { in whom DR-TB } \\
\text { treatment has failed } \\
\text { Home or clinic }\end{array}$ & $\begin{array}{l}\text { Explanation about current } \\
\text { diagnosis; what happens with } \\
\text { treatment of other chronic diseases } \\
\text { or conditions; how to travel safely } \\
\text { if the patient intends to migrate }\end{array}$ & $\begin{array}{l}\text { Session plan - } \\
\text { palliative care } \\
\text { session } \\
\text { Relevant facility } \\
\text { contact details } \\
\text { Referral letter } \\
\text { from clinician }\end{array}$ \\
\hline
\end{tabular}




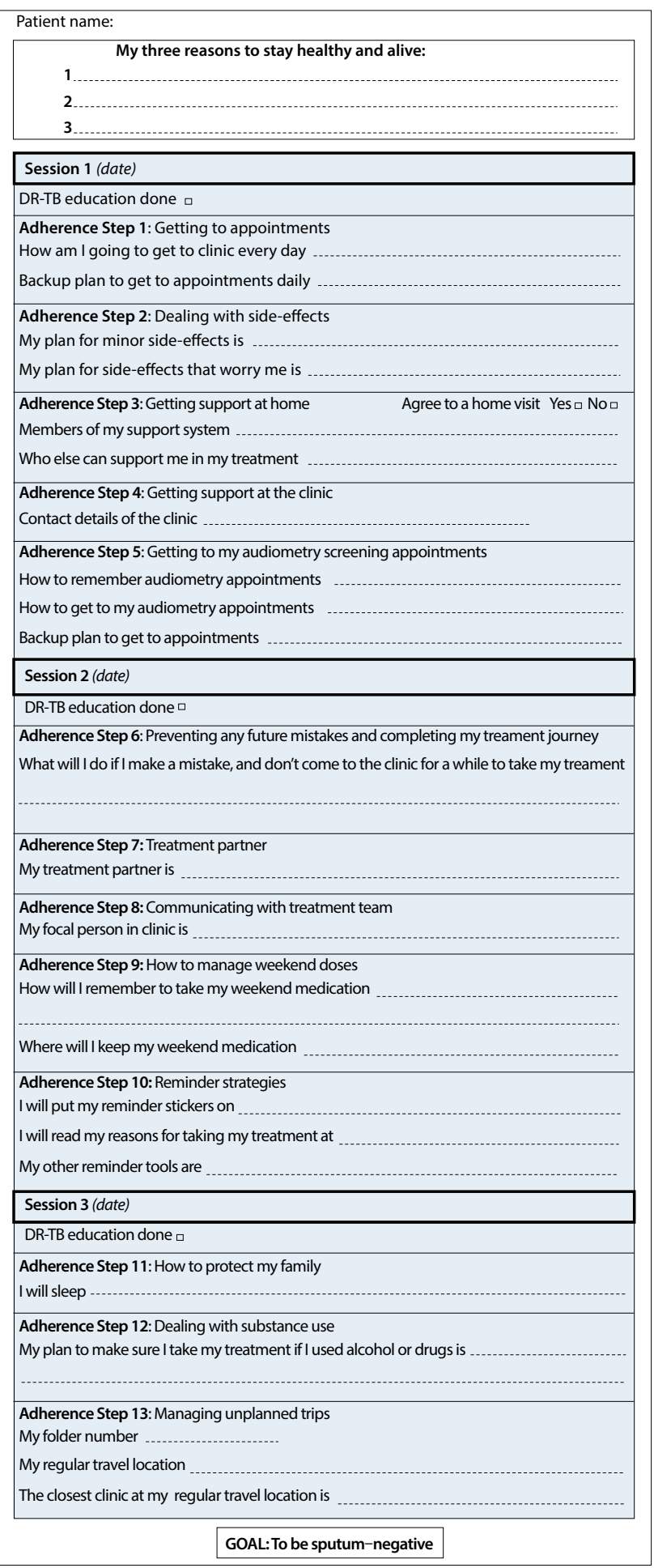

Fig. 2. Sessions 1 - 3 adherence plan for patients. ${ }^{[6]}$

and steps they should follow to overcome commonly experienced barriers to adherence. The initial four sessions are conducted during the intensive phase of treatment (the first three should be conducted within the first 4 weeks of treatment initiation, one of which must be a home visit), with the goals of treatment literacy, stepwise adherence planning, family involvement, contact tracing and infection control advice. In addition to these initial sessions, counselling sessions can occur at any time during treatment to address treatment interruption, the diagnosis of XDR-TB, and treatment failure and palliative care. These additional sessions are particularly important, as they provide detailed scripts for lay counsellors or professional healthcare workers to address very sensitive topics with patients and their families should treatment not yield a successful outcome. Recognising the importance of quality assurance, a counsellor competency assessment for supervisors has also been included in the toolkit. ${ }^{[6]}$ Fig. 1 provides a summary of the timing of the various DR-TB sessions in relation to the patient's journey towards DR-TB treatment completion. Table 1 provides an overview of the contents of the various counselling sessions provided by the DR-TB counsellor to the patient.

While challenges in the implementation of this patient support model can be anticipated, including human resource needs for skilled lay counsellors and their supervision, the structured nature of the approach supports formalised training and monitoring of counsellors and their supervisors. It is further possible to implement counselling sessions in a phased manner to slowly build capacity towards implementing the more specialised XDR-TB and palliative care sessions.

The infrastructure required for the implementation of this toolkit includes four essential components: DR-TB counselling session guides for both the counsellors and their supervisors; adherence plans for patients (Fig. 2); DR-TB flipcharts to use as supportive educational tools during counselling sessions; and a structured training programme for counsellors that contains the tools and exercises necessary to ensure standardised quality of counselling provided to patients.

\section{Conclusions}

The counselling toolkit was presented at the 4th Annual South African Tuberculosis Conference held in Durban, SA, on $10-13$ June 2014. At the conclusion of the conference, the counselling model was recognised for clinical excellence by the organising committee, reinforcing the importance of including a structured patient support component during decentralisation of DR-TB care to primary care level. The DR-TB counsellor is a critical member of the team providing care to patients with DR-TB. It is essential that all DR-TB clinicians, nurses, and counsellors work together to ensure comprehensive support for patients with DR-TB. This support is as essential as the pills patients are required to take every day, and must continue throughout the long DR-TB treatment journey.

Author contributions and funding. EM wrote the article, JH, LS, JC, LW, HD, and VC devised the counselling sessions and toolkit, BB and $\mathrm{XH}$ implemented the counselling sessions, and JC, HD, LW and VC assisted with the revision of the article. All the authors reviewed and approved the final article. The counselling toolkit was funded by MSF.

Ethics approval statement. Since this was a retrospective description of the counselling toolkit which involved no data analyses, no ethical approval was needed.

Acknowledgements. We thank the CCTDoH, the Western Cape Province, the National Health Laboratory Service, Khayelitsha clinic staff, the DRTB counsellors, and most importantly, our patients suffering from DR-TB and HIV in Khayelitsha.

\footnotetext{
1. World Health Organization. Companion Handbook to the WHO Guidelines for the Programmatic Management of Drug-resistant Tuberculosis, 2014. http://apps.who.int/iris/ bitstream/10665/130918/1/9789241548809_eng.pdf (accessed 1 August 2014).

2. Ndjeka N. Multi-Drug Resistant Tuberculosis: Strategic Overview on MDR-TB Care in South Africa. National Department of Health, 2014. https://www.msf.org.za/sites/msf.org.za/files/Publications/ Strategic_overview_of_MDR_TB_RSA.pdf (accessed 1 January 2015).

3. Calligaro G, Dheda K. Drug-resistant tuberculosis. CME 2013;31(9):344-346. http://www.cmej.org.za/ index.php/cmej/article/view/2853/3188 (accessed 1 August 2014).

4. Kendall EA, Theron D, Franke MF, et al. Alcohol, hospital discharge, and socioeconomic risk factors for default from multidrug resistant tuberculosis treatment in rural South Africa: A retrospective cohort study. PLoS One 2013;8(12):e83480. [http://dx.doi.org/10.1371/journal.pone.0083480]

5. Médecins Sans Frontières. Scaling-up diagnosis and treatment of drug-resistant tubercolosis in Médecins Sans Frontières. Scaling-up diagnosis and treatment of drug-resistant tuberculosis in Khayelitsha, South Africa, 2011. http://www.msfaccess.org/sites/default/files/MSF_assets/TB/Docs/ 6. Médecins Sans Frontières. Patient support interventions to improve adherence to drug resistant 6. Médecins Sans Frontières. Patient support interventions to improve adherence to drug resistant
tuberculosis treatment: Counselling toolkit, 2014. http://samumsforg/documents/2014/06/ khayelitsha_dr-tb-pt-support.pdf (accessed 1 August 2014).
}

Accepted 30 May 2015. 